\title{
Cortinarius iodes, a New Record from India
}

\author{
R.K. Verma*, Vimal Pandro, Diwyansh Raj and G.R. Rao \\ Tropical Forest Research Institute, Jabalpur - 482 021, Madhya Pradesh, India \\ *Corresponding author
}

\section{A B S T R A C T}

\section{Keywords}

Cortinarius iodes, Leaf litter, Bridelia retusa and Bauhinia varigata trees

Article Info

Accepted:

18 April 2019

Available Online:

10 May 2019

\section{Introduction}

Cortinarius ia a member of Cortinariaceae, Agaricales was reported to be mycorrhizal with deciduous trees. Cortinarius iodes, commonly known as the spotted cort or the viscid violet cort. This mushroom has no distinctive taste or odor. Although it is edible but not recommended for consumption. The fruit bodies grow singly or in groups on litter.

Fifteen species of genus Cortinarius were reported from India, which mostly occurred from eastern Himalayan and Kerala (Berkeley, 1852; Bhavanidevi and Nair, 1983; Florence, 2004; Chona et al., 1958; Sathe and Daniel 1980; Sathe et al., 1980; Mohanan, 2011; Peintner et al., 2003; Sharma et al., 1978).
In the present article, Cortinarius iodes is reported as a new fungal record from India. Previously the species was reported from North American (Berkeley and Curtis, 1853).

\section{Materials and Methods}

The specimen was collected from campus of Tropical Forest Research Institute, Jabalpur, Madhya Pradesh during September, 2018 (Fig. 12). Identification of fungus was done with the help of literature (Berkeley, 1852; Bhavanidevi and Nair, 1983; Florence, 2004; Chona et al., 1958; Sathe and Daniel 1980; Sathe et al., 1980; Mohanan, 2011; Peintner et al., 2003; Sharma et al., 1978) and matter available on net. The specimen was deposited in the Mycology Herbarium, Tropical Forest Research Institute, Jabalpur. The slides were 
prepared in lacto-phenol and cotton blue and observed under advance Research Microscope, make Leica, Germany and photomicrographs were taken with a digital camera attached to the microscope.

\section{Results and Discussion}

\section{Taxonomic description}

\section{Cortinarius iodes berk. \& M.A. curtis (Figures 1-11)}

(Cortinariaceae, Agaricales, Agaricomycetidae, Agaricomycetes, Agaricomycotina, Basidiomycota) $\equiv$ Gomphos iodes (Berk. \& M.A. Curtis) Kuntze, Revis. gen. pl. (Leipzig) 2: 854 (1891)

The cap is initially bell-shaped before becoming broadly convex and then flat on maturity, and attains a diameter of $5-6.5 \mathrm{~cm}$. The cap surface is slimy (in wet weather) and smooth, and has a lilac or purplish color. The flesh is white, firm, and thin. The color fades on maturity, and the cap develops irregular yellowish spots, or becomes yellowish in the center. Gills are attached to the stem and packed together closely. They are lilac to violet when young, but become rusty brown to grayish cinnamon when the spores mature. The stem measures $5-6 \mathrm{~cm}$ long by $0.8-1 \mathrm{~cm}$ thick, and is nearly equal in width throughout other than a somewhat bulbous base. It is solid slimy, smooth, and has violet or purplish colors that are usually lighter than the cap; sometimes, the stem base is more or less white. The cobweb-like, pale violet partial veil leaves a zone of thin, purple or rusty fibers on the upper stem. Basidia are fourspored, club-shaped, and measuring, 18.75$25 \times 5-12.5 \mu \mathrm{m}$. Basidiospores, rusty-brown, elliptical, with a finely roughened surface, measuring 2.5-6 x 2.5-5 $\mu \mathrm{m}$. Both cheliocystidia and pleurocystidia are absent from the hymenium; the gill edge is populated by basidia and their undeveloped equivalents, basidioles. The cap cuticle comprises a distinctive layer of $5-8 \mu \mathrm{m}$ wide hyphae. Clamp connections are present in hyphae throughout the fruit body.

\section{Collection examined}

On leaf litter growing under Bridelia retusa and Bauhinia varigata trees, near Scientists' hostel building, TFRI Campus, Jabalpur (MP), 31/09/2018; Specimen deposited in pathology museum at Tropical Forest Research Institute (TF 4150).

Cortinarius iodes forms mycorrhizal associations with deciduous trees, particularly oaks. The fruit bodies grow in humus and litter fall, sometimes singly, but more often scattered or in groups under hardwood trees (Mohanan, 2011; Peintner et al., 2003; Roody, 2003). Typical habitats include bog edges, swampy areas, and hummocks. Fruiting usually occurs from July to November. In North America, it is common in eastern regions, and rare in the Pacific Northwest. Its distribution extends from eastern Canada south into Central America and northern regions of South America, northern Asia (Roody, 2003) and it also occurs in Central India.

C. iodes is very similar with $C$. iodeoides in appearance but can be distinguished from the former by its bitter-tasting cap cuticle (Roody, 2003). This species is not reported from India. A purple colored species, C. purpurascens was reported from Chambaghat, Solan, Himachal Pradesh (Sharma et al., 1978). Another similar species reported includes, $C$. traganus, which has a dry, light purple cap and stem and a bad odor (Sundberg and Bessette, 1987). Two other widespread species with violet coloring and slimy caps are C. salor and C. croceocaeruleus (Table $1)$. 
Table.1 Cortinarius species reported from India

\begin{tabular}{|c|c|c|c|c|}
\hline S.N. & Name of fungus & Host/ Substrate & Distribution & Reference \\
\hline 1. & $\begin{array}{l}\text { Cortinarius cinnabarinus } \\
\text { Fr. }\end{array}$ & On ground & $\begin{array}{l}\text { Thiruvananthapuram, } \\
\text { Kerala }\end{array}$ & $\begin{array}{l}\text { Bhavanidevi, Nair (1983); } \\
\text { Florence (2004) }\end{array}$ \\
\hline 2. & $\begin{array}{l}\text { Cortinarius conopileus } \\
\text { K.A. Thomas, M.M. Moser, } \\
\text { Peintner \& Manim. }\end{array}$ & On ground & Wayanad, Kerala & Peintner et al., (2003) \\
\hline 3. & $\begin{array}{l}\text { Cortinarius deceptivus } \\
\text { Kauffman }\end{array}$ & on ground & Delhi & Chona et al., (1958) \\
\hline 4. & $\begin{array}{l}\text { Cortinarius emodensis } \\
\text { Berk. }\end{array}$ & on pine wood & $\begin{array}{l}\text { Lachen, Sikkim, } \\
\text { Himalayas }\end{array}$ & Berkeley (1852) \\
\hline 5. & Cortinarius flammeus Berk. & on pine wood & Sikkim, Himalayas & Berkeley (1852) \\
\hline 6. & $\begin{array}{l}\text { Cortinarius graminicola } \\
\text { Sathe \& S.D. Deshp. }\end{array}$ & on ground & Maharashtra & in Sathe et al., (1980) \\
\hline 7. & $\begin{array}{l}\text { Cortinarius iodes Berk. \& } \\
\text { M.A. Curtis }\end{array}$ & $\begin{array}{l}\text { Growing on litter } \\
\text { under Bridelia } \\
\text { retusa and } \\
\text { Bauhinia varigata } \\
\text { trees }\end{array}$ & $\begin{array}{l}\text { Jabalpur, Madhya } \\
\text { Pradesh }\end{array}$ & This article \\
\hline 8. & $\begin{array}{l}\text { Cortinarius keralensis K.A. } \\
\text { Thomas, M.M. Moser, } \\
\text { Peintner \& Manim. }\end{array}$ & on ground & Wayanad, Kerala & Peintner et al., (2003) \\
\hline 9. & $\begin{array}{l}\text { Cortinarius palmicola Sathe } \\
\text { \& J.T. Daniel (as } \\
\text { Cortinarius palmicolous) }\end{array}$ & on ground & Kollam, Kerala & $\begin{array}{l}\text { in Sathe and Daniel (1980) } \\
\text { Florence (2004) }\end{array}$ \\
\hline 10. & $\begin{array}{l}\text { Cortinarius phlegmophorus } \\
\text { K.A. Thomas, M.M. Moser, } \\
\text { Peintner \& Manim. }\end{array}$ & on ground & Wayanad, Kerala & Peintner et al., (2003) \\
\hline 11. & $\begin{array}{l}\text { Cortinarius pholideus (Lilj.) } \\
\text { Fr. }\end{array}$ & on ground & $\begin{array}{l}\text { Muthanga and Wayanad, } \\
\text { Kerala }\end{array}$ & Mohanan (2011) \\
\hline 12. & $\begin{array}{l}\text { Cortinarius purpurascens } \\
\text { Fr. }\end{array}$ & on soil & $\begin{array}{l}\text { Chambaghat, Solan, } \\
\text { Himachal Pradesh }\end{array}$ & Sharma et al., (1978) \\
\hline 13. & $\begin{array}{l}\text { Cortinarius rufo-olivaceus } \\
\text { (Pers.) Fr. = Cortinarius } \\
\text { vinosus Cooke }\end{array}$ & on pine wood & Sikkim, Himalayas & Berkeley (1852) \\
\hline 14. & $\begin{array}{l}\text { Cortinarius saniosus }(\mathrm{Fr} .) \\
\text { Fr. } \equiv \text { Agaricus saniosus } \mathrm{Fr} .\end{array}$ & on pine wood, & Sikkim, Himalayas & Berkeley (1852) \\
\hline 15. & Cortinarius vinosulus Sacc. & on pine wood & Sikkim, Himalayas & Berkeley (1852) \\
\hline 16. & $\begin{array}{l}\text { Cortinarius violaceus }(\mathrm{L} .) \\
\text { Gray } \equiv \text { Agaricus violaceus } \\
\text { L. }\end{array}$ & on wood & $\begin{array}{l}\text { Myrong, Khasi hills, } \\
\text { Meghalaya }\end{array}$ & Berkeley (1852) \\
\hline
\end{tabular}


Fig.1-2 Cortinarius iodes fruit bodies in habit

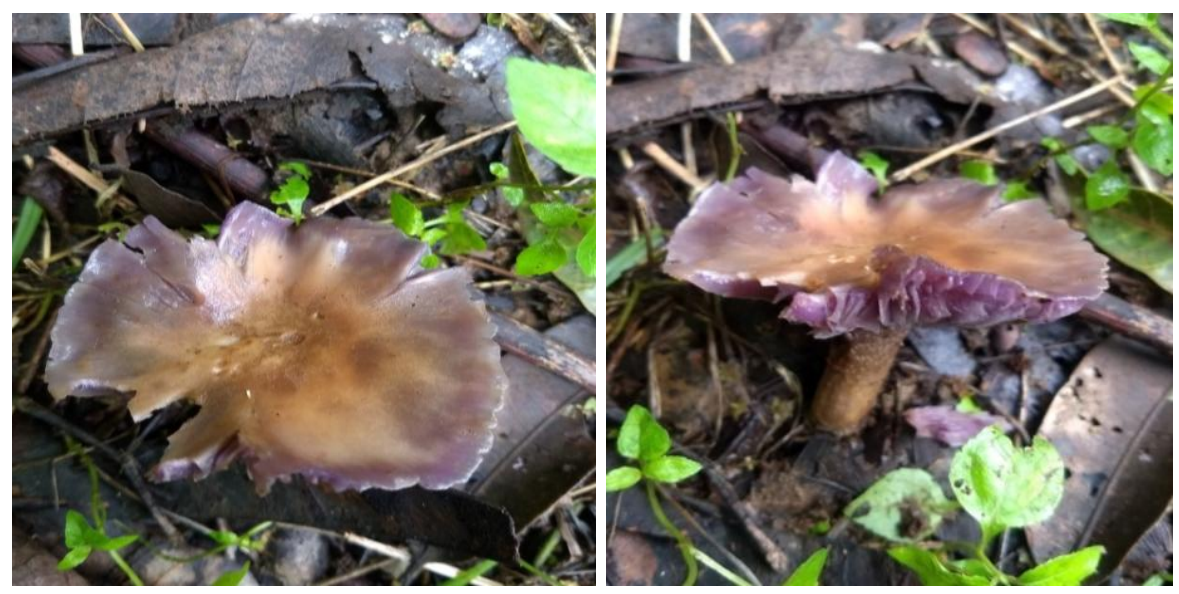

Fig.3-4 Cortinarius iodes fruit bodies in habit showing pileus, gills and stipe

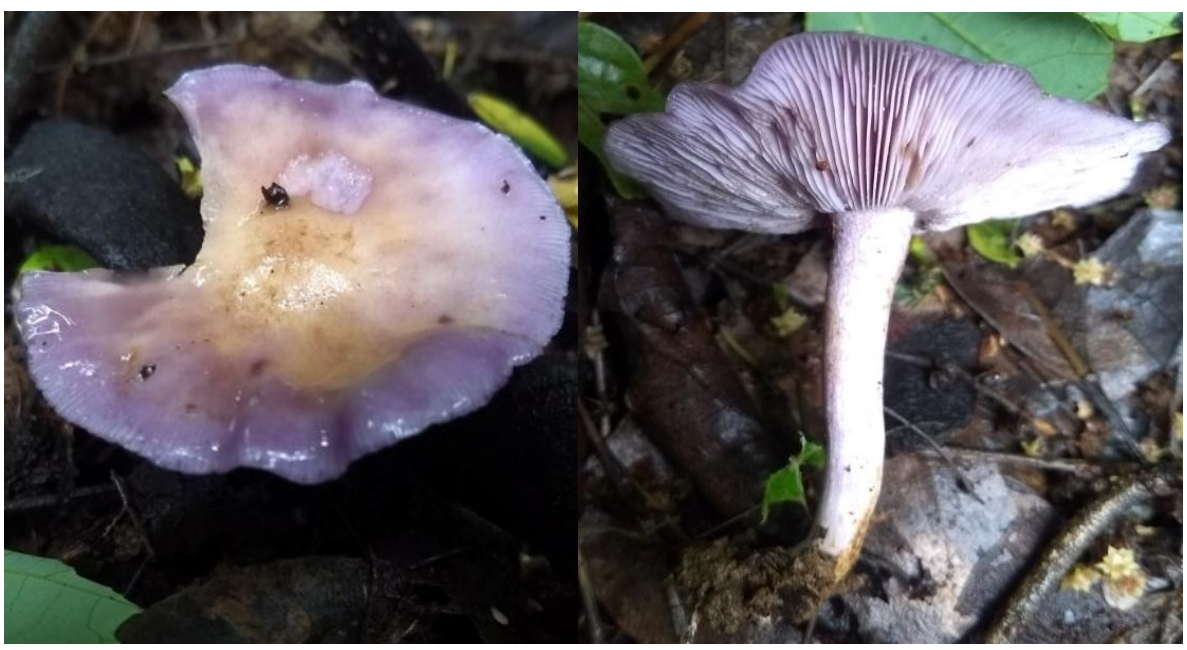

Fig.5-6 Cortinarius iodes, hyphae and section showing basidia

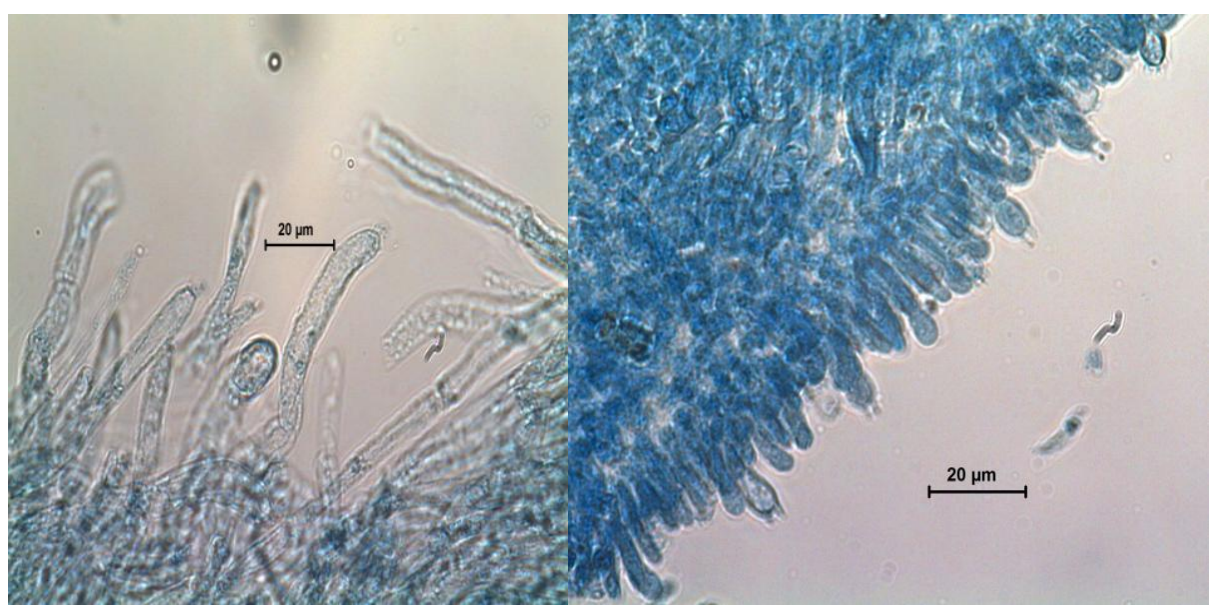


Fig.7-8 Cortinarius iodes section showing basidia and a single basidium
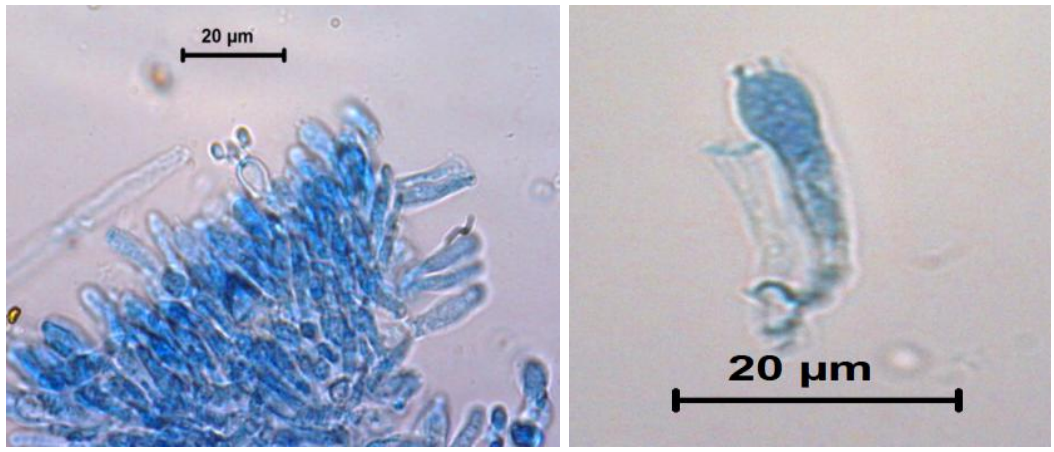

Fig.9-11 Cortinarius iodes, basidiospores in low power and enlarged basidiospores

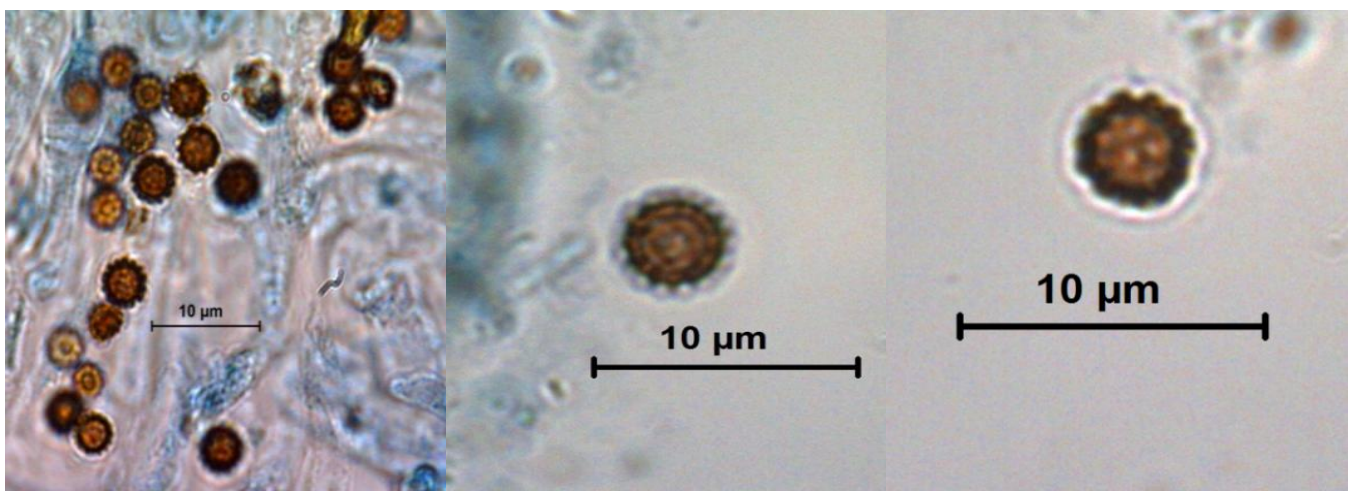

Fig.12 Map of India showing distribution of Cortinarius species

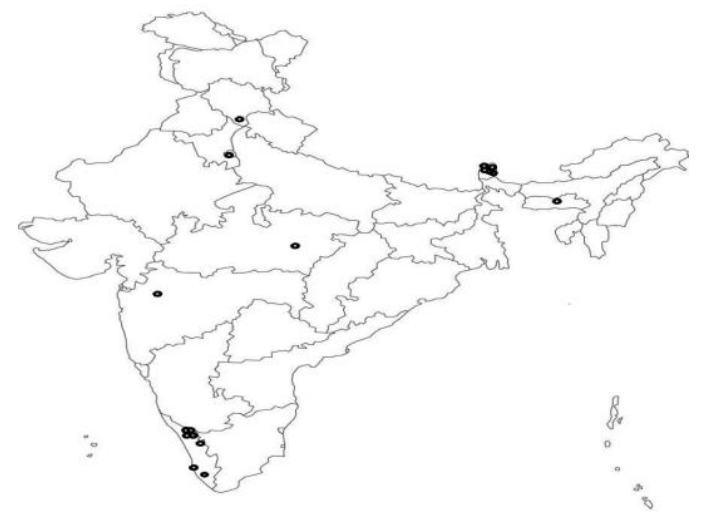

These mushrooms can be distinguished from $C$. iodes by the absence of yellowish spotting (Roberts and Evans, 2011). A North American species $C$. oregonensis has a paler lilac cap with a central region that is yellowish or brownish and with smaller spores (Smith, 1939). Inocybe lilacina, a nonCortinarius species has a dry, silky cap with prominent umbo was also reported (Roody 2003).

In conclusion, Cortinarius iodes growing in litter under Bridelia retusa and Bauhinia varigata trees at Jabalpur, Madhya Pradesh is reported as new fungal record from India. 


\section{Acknowledgement}

The authors are thankful to the Director and Group Coordinator (R), Tropical Forest Research Institute, Jabalpur for providing the research facilities. The work presented here was conducted under project ID No. 224/TFRI/2016/Patho-1(22) funded by Indian Council of Forestry Research \& Education (ICFRE), Dehradun.

\section{References}

Berkeley, MJ., (1851). Decades of fungi. Decades XXXII, XXXIII. Sikkim Himalaya fungi, collected by Dr. J.D. Hooker. Hooker's Journal of Botany and Kew Garden Miscellany 3: 39-49.

Berkeley, MJ., Curtis MA (1853). Centuries of North American fungi. Annals and Magazine of Natural History. 12:417435.

Bhavanidevi, S., Nair MC (1983). Addition to Indian Agaricales. In: Indian Mushroom Science-II (eds TN Kaul, BM Kapoor). CSIR, New Delhi, 271- 274.

Chona, BL., Lal G, Kakria NC (1958). The fungi of Delhi. ICAR Bulletin No. 81 . $43 p$

Florence, EJM., (2004). Biodiversity Documentation for Kerala, Part 2: Microorganisms (Fungi). KFRI Handbook No.17. Kerala Forest Research Institute, Peechi, Kerala, India. Mohanan, C., (2011). Macrofungi of Kerala. Kerala Forest Research Institute, Hand Book \# 27, Kerala, India, 597pp.

Peintner, U, Moser MM, Thomas KA,
Manimohan P (2003). First records of ectomycorrhizal Cortinarius species (Agaricales, Basidiomycetes) from tropical India and their phylogenetic position based on rDNA ITS sequences. Mycological Research 107(4): 485-494.

Roberts, P., Evans S (2011). The Book of Fungi. Chicago, Illinois: University of Chicago Press. p. 100.

Roody, WC., (2003). Mushrooms of West Virginia and the Central Appalachians. Lexington, Kentucky: University Press of Kentucky. p. 193.

Sathe, AV., Daniel J (1980). Agaricales (Mushrooms) of Kerala State. MACS Monograph. No. 1, 75-108.

Sathe, AV., Deshpande S, Kulkarni SM, Daniel J (1980) (1981). Agaricales (Mushrooms) of South-west India - Part I: Agaricales (Mushrooms) of Maharashtra State (MACS, Pune). Pp.1114.

Sharma, AD., Munjal RL, Seth PK (1978). Some fleshy fungi from Himachal Pradesh -III. Indian Journal of Mushroom 4(2): 27-29.

Smith, AH. (1939). Studies in the genus Cortinarius I. Contributions from the University of Michigan Herbarium. 2. Ann Arbor, Michigan: University of Michigan Herbarium. pp. 10-11.

Sundberg, W., Bessette A (1987). Mushrooms: A Quick Reference Guide to Mushrooms of North America (Macmillan Field Guides). New York, New York: Collier Books. p. 84.

\section{How to cite this article:}

Verma, R.K., Vimal Pandro, Diwyansh Raj and Rao, G.R. 2019. Cortinarius iodes, a New Record from India. Int.J.Curr.Microbiol.App.Sci. 8(05): 2306-2311. doi: https://doi.org/10.20546/ijcmas.2019.805.272 